\title{
Phylogenetic and morphological appraisal of Leptosphaeria italica sp. nov. (Leptosphaeriaceae, Pleosporales) from Italy
}

\author{
Dayarathne $\mathrm{MC}^{1,2,3,4}$, Phookamsak $\mathrm{R}^{1,2,3,4}$, Ariyawansa $\mathrm{HA}^{3,4,7}$, Jones E.B.G ${ }^{5}$, \\ Camporesi $\mathrm{E}^{6}$ and Hyde $\mathrm{KD}^{1,2,3,4^{*}}$
}

\footnotetext{
${ }^{1}$ World Agro forestry Centre East and Central Asia Office, 132 Lanhei Road, Kunming 650201, China.

${ }^{2}$ Key Laboratory for Plant Biodiversity and Biogeography of East Asia (KLPB), Kunming Institute of Botany, Chinese Academy of Science, Kunming 650201, Yunnan China

${ }^{3}$ Center of Excellence in Fungal Research, Mae Fah Luang University, Chiang Rai 57100, Thailand

${ }^{4}$ School of Science, Mae Fah Luang University, Chiang Rai 57100, Thailand

${ }^{5}$ Department of Botany and Microbiology, King Saudi University, Riyadh, Saudi Arabia

${ }^{6}$ A.M.B. Gruppo Micologico Forlivese "Antonio Cicognani", Via Roma 18, Forli, Italy; A.M.B. Circolo Micologico "Giovanni Carini”, C.P. 314, Brescia, Italy; Società per gli Studi Naturalistici della Romagna, C.P. 144, Bagnacavallo (RA), Italy

${ }^{7}$ Guizhou Key Laboratory of Agricultural Biotechnology, Guizhou Academy of Agricultural Sciences, Guiyang, 550006, Guizhou, China
}

Dayarathne MC, Phookamsak R, Ariyawansa HA, Jones EBG, Camporesi E and Hyde KD 2015 Phylogenetic and morphological appraisal of Leptosphaeria italica sp. nov. (Leptosphaeriaceae, Pleosporales) from Italy. Mycosphere 6(5), 634-642, Doi 10.5943/mycosphere/6/5/13

\begin{abstract}
A fungal species with bitunicate asci and ellipsoid to fusiform ascospores was collected from a dead branch of Rhamnus alpinus in Italy. The new taxon morphologically resembles Leptosphaeria. Maximum likelihood (ML) and Bayesian analyses of a combined LSU and ITS sequence dataset confirm its placement in Leptosphaeria sensu stricto. The new taxon is distinct from other species based on morphology and phylogeny and is thus introduced as a new species, viz. L. italica. The new species is compared with other Leptosphaeria species and a comprehensive description and micrographs are provided.
\end{abstract}

Key words - ITS - LSU - molecular phylogeny - morphology - taxonomy

\section{Introduction}

Leptosphaeriaceae is an important group of fungi in the order Pleosporales (Zhang et al. 2012, Hyde et al. 2013), including economically important pathogens on a number of hosts (De Gruyter et al. 2013, Hyde et al. 2014). Barr (1987) introduced the family Leptosphaeriaceae and typified it with the genus Leptosphaeria, with L. doliolum (Pers.) Ces. \& De Not. as the type species. The genus Leptosphaeria is saprobic or pathogenic on stems and leaves of herbaceous or woody plants in terrestrial and possibly aquatic habitats (Ariyawansa et al. 2015, Jones et al. 2015). Eriksson \& Hawksworth $(1986,1990)$ accepted Barr's separation of Leptosphaeriaceae from Pleosporaceae. Leptosphaeriaceae is phylogenetically well-established in the suborder Pleosporineae (Schoch et al. 2009, Zhang et al. 2012, Wijayawardene et al. 2014, Ariyawansa et al. 2015). Even though the family shares some similarities with Phaeosphaeriaceae, it can clearly be distinguished by its peridium structure, hosts and asexual morphs (Câmara et al. 2002). The members of Submitted 6 October 2015, Accepted 28 October 2015, Published online 31 October 2015 
Leptosphaeriaceae occur abundantly on dicotyledons and have a relatively wide peridium comprising scleroplectenchymatous cells with coniothyrium-like and phoma-like asexual morphs (Câmara et al. 2002, Kirk et al. 2008, Zhang et al. 2009, Wijayawardene et al. 2012, Hyde et al. 2013, Phookamsak et al. 2014). Phaeosphaeriaceae species are commonly found on monocotyledons and the peridium is relatively thin, comprising pseudoparenchymatous cells (Câmara et al. 2002, Kirk et al. 2008, Zhang et al. 2009, 2012, Hyde et al. 2013, Phookamsak et al. 2014).

In the wider sense, the genus Leptosphaeria is characterized by superficial ascomata with thick-walled, scleroplectenchymatous cells, arranged in a textura angularis, with an outer black amorphous layer not fusing with the host tissues and pale to dark brown, septate ascospores in bitunicate asci (Camara et al. 2002, Ariyawansa et al. 2015). The asexual morphs of Leptosphaeria are coniothyrium-like and phoma-like, comprising depressed, globose conidiomata, with a flattened base and cylindrical necks. The conidiomata wall is scleroplectenchymatous and conidia ellipsoidal to subcylindrical (Boerema et al. 1994, Hyde et al. 2011, Wijayawardene et al. 2012).

The objectives of this study are to 1) introduce a new species in Leptosphaeria, and 2) investigate its taxonomic placement using maximum likelihood and Bayesian analyses of combined LSU and ITS sequence data, based on the backbone tree provided by Ariyawansa et al. (2015).

\section{Material and methods}

A Dothideomycete species was collected from a dead branch of a deciduous tree in Italy, and dried herbarium material is deposited at the Mae Fah Luang University herbarium, Thailand (MFLU) and the Herbarium of Kunming Institute of Botany (HKAS), China. Slides were prepared by hand-sectioning of dried material and examined under the Olympus SZH10 stereo microscope. Morphological structures were examined by compound light microscope (Nikon Eclipse 80i compound microscope) and photomicrography carried out using a Canon 550D digital camera fitted to the microscope. Measurements of characters were made with Tarosoft (R) Image Frame Work version 0.9.7, measurements are based on up to 30 units and are reported as the extremes (maximum and minimum).

Faces of fungi numbers were obtained as explained in Jayasiri et al. (2015) and IF numbers in Index Fungorum (2015).

\section{DNA extraction, PCR amplification and gene sequencing}

DNA was extracted directly from ascomata using a DNA extraction kit (E.Z.N.A.® Forensic DNA kit, D3591- 01,Omega Bio-Tek) following the manufacturer's instructions.

The partial large subunit nuclear rDNA (28S, LSU) was amplified with primers LROR and LR5 (Vilgalys and Hester 1990). The internal transcribed spacers (5.8S, ITS) were amplified by ITS4 and ITS5 primer pairs as described by White et al. (1990). The components for the PCR were used as follows. The final volume of the PCR mixture was $25 \mu \mathrm{l}$ with $1.0 \mu \mathrm{l}$ of DNA template, $1 \mu \mathrm{l}$ of each forward and reverse primers, $12.5 \mu \mathrm{l}$ of $2 \times$ Easy Taq PCR Super Mix (mixture of Easy Taq TM DNA Polymerase, dNTPs, and optimized buffer, Beijing Trans Gen Biotech Co., Chaoyang District, Beijing, PR China) and $9.5 \mu 1$ sterilized water.

The amplification was performed with an initial denaturing step of $94{ }^{\circ} \mathrm{C}$ for $3 \mathrm{~min}$, followed by 30 amplification cycles of $94{ }^{\circ} \mathrm{C}$ for $30 \mathrm{~s}$ and $55^{\circ} \mathrm{C}$ for $50 \mathrm{~s}$ for annealing and $72{ }^{\circ} \mathrm{C}$ for $1 \mathrm{~min}$ and a final extension step of $72{ }^{\circ} \mathrm{C}$ for $10 \mathrm{~min}$ (Phillips et al. 2008). The PCR products were observed on $1 \%$ agarose electrophoresis gels stained with ethidium bromide. Purification and DNA sequencing was performed by Shanghai Sangon Biological Engineering Technology \& Services Co. (Shanghai, P.R. China). The nucleotide sequence data acquired were deposited in GenBank (Table 1).

\section{Phylogenetic analyses}

Phylogenetic analyses was based on ITS and LSU sequence data and sequence homologies using the BLAST search engine of the National Centre for Biotechnology Information (NCBI) for 
the preliminary identification of the new isolate (Udayanga et al. 2012). Sequences of the available closely related taxa from the family Leptosphaeriaceae were obtained from GenBank following Ariyawansa et al. (2015) (Table 1). Members of the genus Leptosphaeria was included in this analyses, with Alternariaster helianthi as an outgroup taxon.

Table 1 Taxa used in the phylogenetic analyses and their corresponding GenBank numbers. The newly generated sequences are indicated in blue and ex-type isolates are in bold.

\begin{tabular}{|c|c|c|c|}
\hline \multirow[t]{2}{*}{ Taxon } & \multirow[t]{2}{*}{ Culture Accession No } & \multicolumn{2}{|c|}{ GenBank Accession } \\
\hline & & ITS & LSU \\
\hline Alloleptosphaeria italica & MFLUCC 14-0934 & KT454722 & KT454714 \\
\hline Alternariaster helianthi & CBS 327.69 & КС609335 & KC584369 \\
\hline Leptospharia ebuli & MFLU 14-0828 & KP744446 & KP744488 \\
\hline \multirow[t]{5}{*}{ Leptosphaeria errabunda } & CBS 129998 & JF740219 & - \\
\hline & CBS 129999 & JF740218 & - \\
\hline & CBS 129997 & JF740220 & - \\
\hline & CBS 617.75 & JF740216 & JF740289 \\
\hline & CBS 125978 & JF740217 & JF740290. \\
\hline Leptosphaeria macrocapsa & CBS 640.93 & JF740237 & JF740304 \\
\hline \multirow[t]{7}{*}{ Leptospharia doliolum } & CBS 541.66 & JF740206 & JF740284 \\
\hline & CBS 504.75 & JF740209 & JX681095 \\
\hline & CBS 130000 & JF740210 & - \\
\hline & CBS 155.94 & JF740207 & JF740282 \\
\hline & CBS 505.75 & JF740205 & GQ387576 \\
\hline & CBS 125979 & JF740208 & JF740283 \\
\hline & MFLUCC 15-1875 & KP729444 & KP729445 \\
\hline \multirow[t]{2}{*}{ Leptosphaeria veronicae } & CBS 145.84 & JF740254 & JF740320 \\
\hline & CBS 126583 & JF740255 & JF740321 \\
\hline \multirow[t]{2}{*}{ Leptosphaeria conoidea } & CBS 616.75 & JF740201 & JF740279 \\
\hline & CBS 125977 & JF740202 & JF740280 \\
\hline \multirow[t]{2}{*}{ Leptosphaeria sclerotioides } & CBS 144.84 & JF740192 & JF740269 \\
\hline & CBS 148.84 & JF740193 & JF740270 \\
\hline \multirow[t]{2}{*}{ Leptosphaeria slovacica } & CBS 389.80 & JF740247 & JF740315 \\
\hline & CBS 125975 & JF740248 & JF740316 \\
\hline Leptosphaeria sydowii & CBS 385.80 & JF740244 & JF740313 \\
\hline & CBS 125976 & JF740245 & JF740314 \\
\hline Leptosphaeria italica & MFLU 15-0174 & KT443984 & KT783670 \\
\hline \multirow[t]{2}{*}{ Leptosphaeria pedicularis } & CBS 390.80 & JF740224 & JF740294 \\
\hline & CBS 126582 & JF740223 & JF740293 \\
\hline Leptosphaeria cichorium & MFLUCC 14-1063 & KT454720 & KT454712 \\
\hline \multirow[t]{2}{*}{ Neoleptosphaeria rubefaciens } & CBS 223.77 & JF740243 & JF740312 \\
\hline & CBS 387.80 & JF740242 & JF740311 \\
\hline Pseudoleptosphaeria etheridgei & CBS 125980 & NR111620 & JF740291 \\
\hline
\end{tabular}

Abbreviations - CBS: Centraalbureau voor Schimmelcultures, Utrecht, The Netherlands; MFLUCC: Mae Fah Luang University Culture Collection, Chiang Rai, Thailand.

Multiple sequence alignments were generated with MAFFT v. $6.864 \mathrm{~b}$ (http://mafft.cbrc.jp/alignment/server/index.html). The alignments were checked visually and improved where necessary and manually optimized to allow maximum alignment and maximum 
sequence similarity as detailed in Hall (1999) and ClustalX (Kohli \& Bachhawat 2013). Best-fit model of evolution for each data set for Bayesian and Maximum Likelihood analyses was determined by MrModeltest 2.2 (Nylander 2004).

Maximum likelihood trees were generated using the RAxML software (Stamatakis et al. 2008) implemented in raxmlGUI v.0.9b2 (Silvestro \& Michalak 2010), Rapid bootstrap with nonparametric bootstrap iterations (Stamatakis et al. 2008) was run in 1,000 replicates with the GTR model and a discrete gamma distribution (Liu et al. 2011). The best scoring tree from a separate randomized tree under the same model was selected with a final likelihood value of 4057.667790 and data files were viewed in MEGA v. 5 (Tamura et al. 2011).

The model of nucleotide substitution was estimated using Topali v. 2.5 and Bayesian inference (BI) analyses computed by Topali 2.5 (Milne et al. 2004). The likelihood parameters for BI were based on the GTR+G model. Posterior probabilities (PP) were estimated over 5000000 generations via four independent runs of four simultaneous MCMCMC chains with every 100th tree saved. The first $25 \%$ of the sampled trees were discarded as 'burn in'. Bayesian Posterior Probabilities (PP) equal or greater than 0.90 is given below or above each node (Fig. 1). Phylogenetic trees and data files were viewed in MEGA v. 5 (Tamura et al. 2011), TreeView v. 1.6.6 (Page 1996) and FigTree v. 1.4 (Rambaut \& Drummond 2008).

\section{RESULTS}

\section{Phylogenetic analyses}

The results obtained by both maximum likelihood (ML) and Bayesian inference (BI) analyses of the combined LSU and ITS dataset comprised 33 taxa including the new strain were identical. The new strain, Leptosphaeria italica (MFLU 15-0174), grouped in Leptosphaeria sensu stricto in Leptosphaeriaceae and formed a distinct clade with low bootstrap support (Fig. 1).

\section{TAXONOMY}

Leptosphaeria italica M.C. Dayarathne, Camporesi \& K.D. Hyde, sp. nov

Index Fungorum number: IF551552; Facesoffungi Number: FoF01040

Fig. 2

Etymology - Name reflects the country Italy, from where the species was collected.

Holotype - MFLU 15-2251

Saprobic on dead branch of Rhamnus alpinus. Sexual morph: Ascomata 285-294 $\mu \mathrm{m}$ high, 248-260 $\mu \mathrm{m}$ diam., solitary to gregarious, superficial or semi-immersed on host tissue, visible as black spots on host surface, sometimes bi-loculate, globose to subglobose, brown to dark brown, Ostiole apex dark brown to black, ostiolar canal filled with periphyses, papilla not conspicuous Peridium 38-40 $\mu \mathrm{m}$ wide, comprising two cell types, outer layer composed of large, heavily pigmented, thick-walled cells of textura angularis, inner layer composed of scleroplectenchymatous cells of textura angularis. Hamathecium comprising numerous, 1-2 $\mu \mathrm{m}$ diam., slime coated, branched, cellular pseudoparaphyses. Asci $60-112 \times 7-12 \mu \mathrm{m}(\bar{x}=86 \times 9.5$ $\mu \mathrm{m}, \mathrm{n}=30$ ), 8-spored, bitunicate, numerous, cylindrical to cylindric-clavate, short pedicellate, apically rounded, with indistinct ocular chamber. Ascospores $12-18 \times 4-6 \mu \mathrm{m}(\bar{x}=15 \times 5 \mu \mathrm{m}, \mathrm{n}=$ 30), uni to bi-seriate, pale brown when immature, becoming yellowish brown to brown at maturity, ellipsoid to broadly fusiform, with rounded to acute ends, slightly clavate with narrow towards the base, 3-septate, rarely 1-2 septate, strongly constricted at septum, widest above the central septum, smooth-walled. Asexual morph: Undetermined.

Known distribution - On dead and hanging branches of Rhamnus alpinus, Italy.

Material examined - ITALY. Province of Forlì-Cesena [FC], Monte Fumaiolo, on dead and hanging branches of Rhamnus alpinus L. ssp. Fallax (Boiss.) Marie \& Petitmangin (Rhamnaceae), 17 March 2014, E. Camporesi, IT-1766 (MFLU 15-0174, holotype), (isotype in HKAS, under the code of HKAS 86440). 


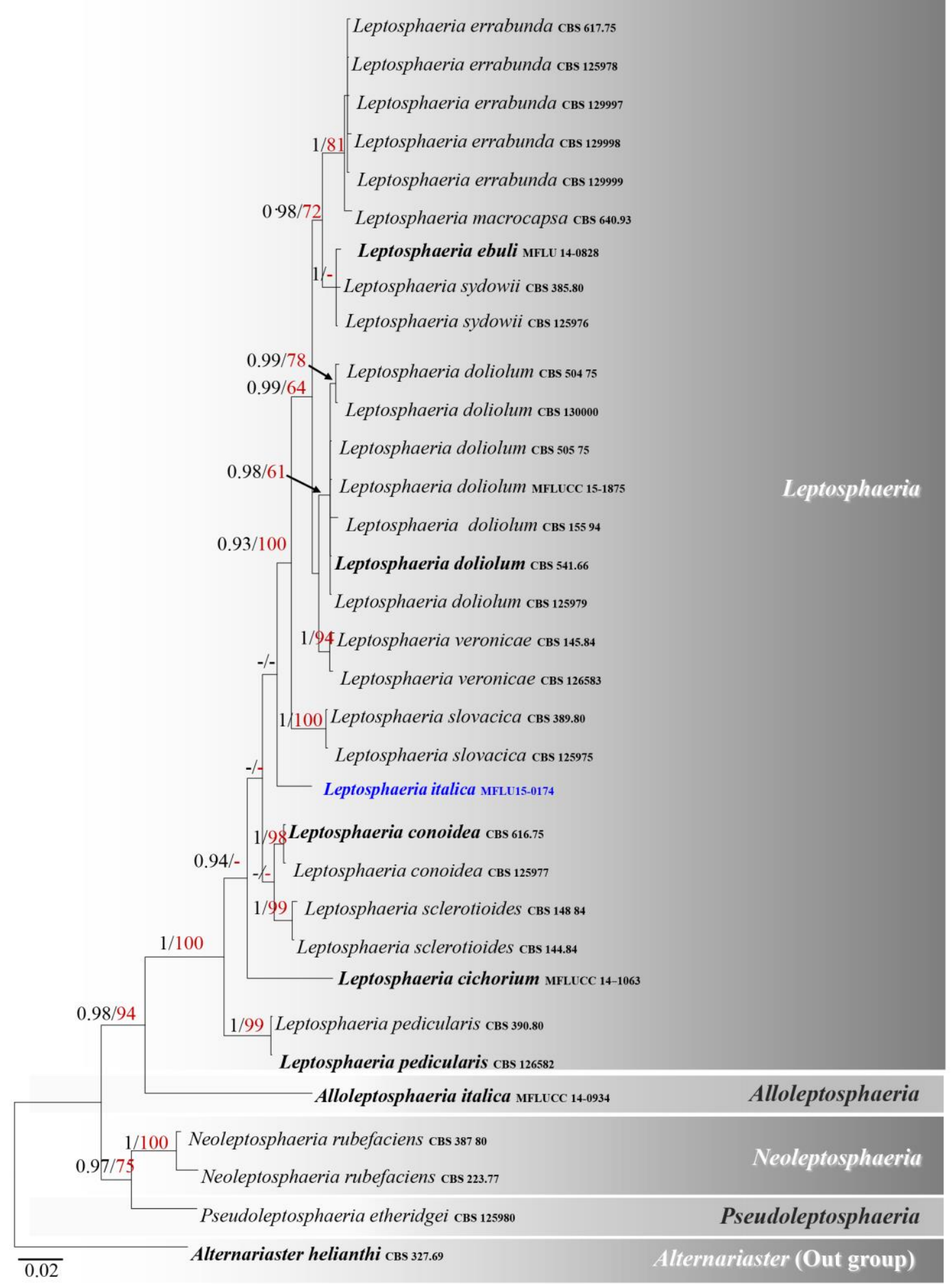

Fig. 1 - Bayesian 50\% majority rule consensus tree based on analyses of a combined dataset of LSU and ITS partial sequence data. Bootstrap values for maximum likelihood (ML, blue) higher than $60 \%$ and Bayesian posterior probabilities (PP, black) greater than 0.90 are given above the nodes. The tree is rooted to Alternariaster helianthi (CBS 327.69). All ex-type strains are in bold.

Notes - Single spore isolation was not successful and DNA was extracted directly from the fresh fruiting bodies. Therefore, living cultures are not available.

Gene sequence data - ITS (KT443984), LSU (KT783670). 

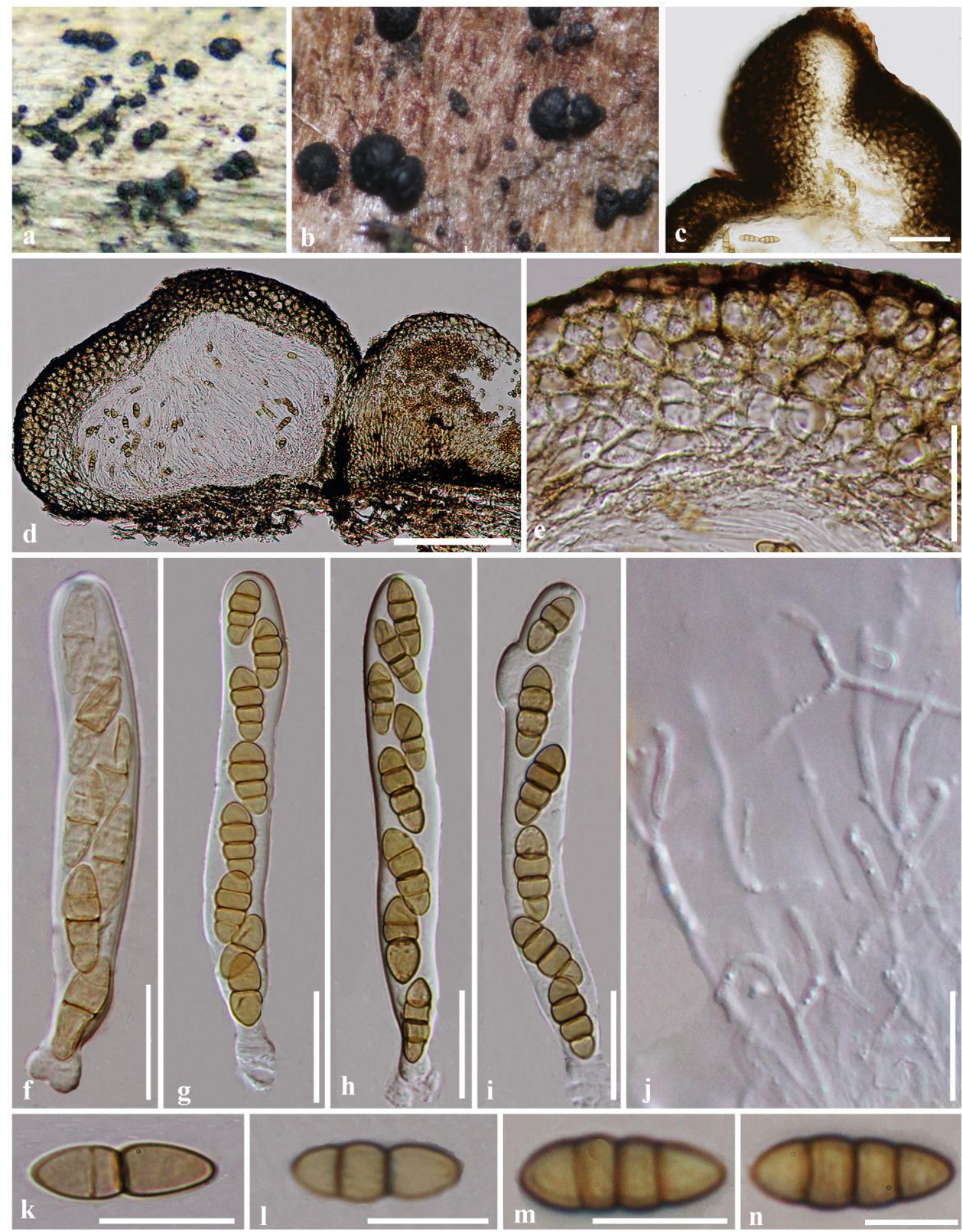

Fig. 2 - Leptosphaeria italica (MFLU15-0174, holotype). a, b. Ascomata on host. c. Section through ostiolar region. d. Section through ascoma. e. Peridium. f-i. Asci. j. Pseudoparaphyses. k-n. Ascospores. Scale bars: $d=100 \mu \mathrm{m}, \mathrm{c}, \mathrm{e}=50 \mu \mathrm{m}, \mathrm{f}-\mathrm{j}=20 \mu \mathrm{m}, \mathrm{k}-\mathrm{n}=10 \mu \mathrm{m}$.

\section{Discussion}

The genus Leptosphaeria was introduced by Cesati \& de Notaris (1863) comprising 26 species, with $L$. doliolum as the lectotype species (Shearer et al. 1990). Material used by Persoon (1800) in the National Herbarium Netherlands, Leiden University (L), was selected to lectotypify $S$. doliolum the basionym of Leptosphaeria doliolum (Shearer et al. 1990). Leptosphaeria sensu stricto species are characterized by a peridium of scleroplectenchymatous cells and 3-septate, reddish to yellowish brown ascospores, which are narrowly fusoid with sharp to narrowly rounded ends, and with the cell above the central septum widest (Ariyawansa et al. 2015). 
Leptosphaeria italica is saprobic on dead stems of Rhamnus alpines and has (1-2-) 3-septate, yellowish brown to brown, ellipsoid to fusiform, somewhat clavate ascospores $(12-18 \times 4-6 \mu \mathrm{m})$, strongly constricted at the septa, with the cell above central septum widest and thus differs from $L$. doliolum. As far as we are aware, no Leptosphaeria are known from Rhamnus alpinus. We compared the new strain with Melanomma fuscidulum Sacc. from Rhamnus sp. and they share some similar characters, but M. fuscidulum differs from L. italica with ascospore size $(12-18 \times$ 3.5-4 $\mu \mathrm{m}$ ) and being 2-celled (Saccardo 1878). In our combined analyses of ITS and LSU sequence data of members of the family Leptosphaeriaceae, taxa from the genus Leptosphaeria sensu stricto formed a distinct clade including L. errabunda (Desm.) Gruyter, Aveskamp \& Verkley, L. macrocapsa (Trail) Gruyter, Aveskamp \& Verkley, L. sydowii (Boerema, Kesteren \& Loer.) Gruyter, Aveskamp \& Verkley, L. ebuli Jayasiri, Camporesi \& K.D. Hyde, L. veronicae (Hollós) Gruyter, Aveskamp \& Verkley, L. doliolum, L. conoidea (De Not.) Sacc., L. sclerotioides (Preuss ex Sacc.) Gruyter, Aveskamp \& Verkley, L. slovacica Picb., L. pedicularis (Fuckel) Gruyter, Aveskamp \& Verkley, L. cichorium Phukhamsakda, Camporesi, Ariyawansa \& K.D. Hyde and our new species $L$. italica, the latter forming a distinct lineage with comparatively low statistical support (Figure 1). Leptosphaeria italica has similar features to L. solani Romell ex Berl. and $L$. slovacica. Leptosphaeria solani differs from L. italica in having narrowly clavate to elliptical asci, and ascospores with globose terminal appendages (Shoemaker 1984). Leptosphaeria slovacica is phylogenetically distantly related to L. italica, and ascospores of L. slovacica differ in being broadly fusiform, 3 -septate, and olivaceous yellow with acute end cells.

\section{Acknowledgements}

We would like to thank CGIAR Research Program 1.2 - Humidtropics: Integrated systems for the humid tropics. Gareth Jones would like to acknowledge research grant Award Number (12BIO2840-02.K.L) of the National Plan for Science, Technology and Innovation (MAARIFAH), King Abdulaziz City for Science and Technology, Fungal Diversity Kingdom of Saudi Arabia. Liu Ende, Assistant Curator, Herbarium, Kunming Institute of Botany, Chinese Academy of Sciences (KUN), Kunming, China and Saranyaphat Boonmee, Curator, MFLU Herbarium, The Institute of Excellence in Fungal Research, Mae Fah Luang University, Chiang Rai, Thailand are also acknowledged. Erio Camporesi thanks to Sergio Montanari for the identification of the host plant. Monika Dayarthne thanks to Dhanushka Wanasinghe, Dongqin Dai, Hansika Perera, Samantha Karunarathna, Nalin Wijayawardene and K. Thambugala for their valuable suggestions and help.

\section{References}

Ariyawansa HA, Phukhamsakda C, Thambugala KM, Bulgakov TS, Wanasinghe DN, Perera RH, Mapook A, Camporesi E, Kang JC, Jones EBG, Bahkali AH, Jayasiri SC, Hyde KD. 2015 Revision and phylogeny of Leptosphaeriaceae. Fungal Diversity (DOI 10.1007/s13225015-0349-2).

Barr ME. 1987 - Prodromus to class Loculoascomycetes. Amherst, Massachusetts: Hamilton I. Newell, Inc. 168 p.

Boerema GH, de Gruyter J, Kesteren HA van. 1994 - Contributions towards a monograph of Phoma (Coelomycetes) - III-1. Section Plenodomus: Taxa often with a Leptosphaeria teleomorph. Persoonia 15, 431-487.

Câmara MPS, Palm ME, Berkum P van, O’Neill NR. 2002 - Molecular phylogeny of Leptosphaeria and Phaeosphaeria. Mycologia 94, 630-640.

Cesati V, de Notaris G. 1863 - Schema di classificazione deglesferiacei italici aschigeri piu' o meno appartenenti al genere Sphaeria nell'antico significato attribuitoglide Persono. Comm Soc crittog Ital 1, 177-420.

de Gruyter J, Woudenberg JHC, Aveskamp MM, Verkley GJM, Groenewald JZ, Crous PW. 2013 Redisposition of phoma-like anamorphs in Pleosporales. Studies in Mycology 75, 1-36. 
Eriksson O, Hawksworth DL. 1986 - Outline of the Ascomycetes 1986. Systema Ascomycetum 5, $185-324$.

Eriksson O, Hawksworth DL. 1990 - Outline of the Ascomycetes \pm 1989 . Systema Ascomycetum 8, 119-318.

Hall T. 2004 - BioEdit v. 7.0.1. Department of Microbiology, North Carolina State University. Available at www.mbio.ncsu.edu/ BioEdit/bioedit.html.

Hyde KD, Jones EBG, Liu JK, Ariyawansa H, Boehm E, Boonmee S, Braun U, Chomnunti P, Crous PW, Dai DQ, Diederich P, Dissanayake A, Doilom M, Doveri F, Hongsanan S, Jayawardena R, Lawrey JD, Li YM, Liu YX, Lücking R, Monkai J, Muggia L, Nelsen MP, Pang KL, Phookamsak R, Senanayake IC, Shearer CA, Suetrong S, Tanaka K, Thambugala $\mathrm{KM}$, Wijayawardene NN, Wikee S, Wu HX, Zhang Y, Aguirre-Hudson B, Alias SA, Aptroot A, Bahkali AH, Bezerra JL, Bhat DJ, Camporesi E, Chukeatirote E, Gueidan C, Hawksworth DL, Hirayama K, Hoog SD, Kang JC, Knudsen K, Li WJ, Li XH, Liu ZY, Mapook A, McKenzie EHC, Miller AN, Mortimer PE, Phillips AJL, Raja HA, Scheuer C, Schumm F, Taylor JE, Tian Q, Tibpromma S, Wanasinghe DN, Wang Y, Xu JC, Yacharoen S, Yan JY, Zhang M. 2013 - Families of Dothideomycetes. Fungal Diversity 63, $1-313$.

Hyde KD, McKenzie EHC, KoKo TW. 2011 - Towards incorporating anamorphic fungi in a natural classification - checklist and notes for 2010. Mycosphere 2, 1-88.

Hyde KD, Nilsson RH, Alias SA, Ariyawansa HA, Blair JE, Cai L, de Cock AWAM, Dissanayake AJ, Glockling SL, Goonasekara ID, Gorczak M, Hahn M, Jayawardena RS, van Kan JAL, Laurence MH, Lévesque CA, Li X, Liu JK, Maharachchikumbura SSN, Manamgoda DS, Martin FN, McKenzie EHC, McTaggart AR, Mortimer PE, Nair PVR, Pawłowska J, Rintoul TL, Shivas RG, Spies CFJ, Summerell BA, Taylor PWJ, Terhem RB, Udayanga D, Vaghefi N, Walther G, Wilk M, Wrzosek M, Xu JC, Yan JY, Zhou N. 2014 - One stop shop: backbones trees for important phytopathogenic genera: I (2014). Fungal Diversity 67(1), 21-125.

Jayasiri CS, Hyde KD, Ariyawansa HA, Bhat J, Buyck B, Cai L, Dai YC, Abd-Elsalam KA, Ertz D, Hidayat I, Jeewon R, Jones EBG, Bahkali AH, Karunarathna SC, Liu JK, Luangsa-ard JJ, Lumbsch HT, Maharachchikumbura SSN, McKenzie EHC, Moncalvo JM, Ghobad-Nejhad M, Nilsson H, Pang KL, Pereira OL, Phillips AJL, Raspé O, Rollins AW, Romero AI, Etayo J, Selçuk F, Stephenson SL, Suetrong S, Taylor JE, Tsui CKM, Vizzini A, AbdelWahab MA, Wen TC, Boonmee S, Dai DQ, Daranagama DA, Dissanayake AJ, Ekanayaka AH, Fryar SC, Hongsanan S, Jayawardena RS, Li WJ, Perera RH, Phookamsak R, De Silva NI, Thambugala KM, Tian Q, Wijayawardene NN, Zhao RL, Zhao Q, Kang JC, Promputtha I. 2015 - The Faces of Fungi database: fungal names linked with morphology, phylogeny and human impacts. Fungal diversity (In press).

Jones EBG, Suetrong S, Sakayaroj J, Bahkali AH, Abdel-Wahab MA, Boekhout T, Pang KL. 2015 - Classification of marine Ascomycota, Basidiomycota, Blastocladiomycota and Chytridiomycota. Fungal Diversity 73, 1-72.

Kirk PM, Cannon PF, Minter DW, Stalpers JA . 2008 - Ainsworth \& Bisby's dictionary of the fungi, 10th edn. CABI, Wallingford.

Kohli DK, Bachhawat AK. 2003 - CLOURE: Clustal Output Reformatter, a program for reformatting ClustalX/ClustalW outputs for SNP analyses and molecular systematics. Nucleic Acids Research 31(13), 3501-3502.

Liu JK, Phookamsak R, Jones EBG, Zhang Y, Ko-Ko TW, Hu HL, Boonmee S, Doilom M, Chukeatirote E, Bahkali AH, Wang Y, Hyde KD. 2011-Astrosphaeriella is polyphyletic, with species in Fissuroma gen. nov., and Neoastrosphaeriella gen. nov. Fungal Diversity $51,135-154$.

Milne I, Wright F, Rowe G, Marshal DF, Husmeier D, McCuire G. 2004 - TOPALi: Software for automatic identification of recombinant sequences within DNA multiple alignments. Bioinformatics 20, 1806-1807. 
Nylander JAA. 2004 - MrModeltest 2.0. Program distributed by the author. Evolutionary Biology Centre, Uppsala University.

Persoon CH. 1800 - Icones et description Fugorum-minus cognitorum 2, 27-67 Lispsiae.

Phookamsak R, Liu JK, McKenzie EHC, Manamgoda DS, Ariyawansa HA, Thambugala KM, Dai DQ, Camporesi E, Chukeatirote E, Wijayawardene NN, Bahkali AH, Mortimer PE, Xu JC, Hyde KD. - 2014 Revision of Phaeosphaeriaceae. Fungal Diversity 68, 159-238.

Phillips AJL, Alves A, Pennycook SR, Johnston PR, Ramaley A, Akulov A, Crous PW. 2008 Resolving the phylogenetic and taxonomic status of dark-spored teleomorph genera in the Botryosphaeriaceae. Persoonia 21, 29-55.

Rambaut A, Drummond A. 2008 - FigTree: Tree figure drawing tool, version 1.2. 2. Institute of Evolutionary Biology, University of Edinburgh.

Romell ex B. 1890 - Leptosphaeria solani. Icones Fungorum - 1(1), 63.

Saccardo PA. 1878 - Fungi Veneti novi vel critici. Series III (reprint from 1875, Hedwigia 5: 6876). Michelia. 1(4), 446-452.

Schoch CL, Crous PW, Groenewald JZ, Boehm EWA, Burgess TI. 2009 - A classwide phylogenetic assessment of Dothideomycetes. Studies in Mycology 64, 1-15.

Shearer CA, Crane JL, Chandra Reddy KR. 1990 - Studies in Leptosphaeria. Lectotypification of Sphaeria doliolum. Mycologia 82, 496-500.

Shoemaker RA. 1984 - Canadian and some extralimital Leptosphaeria species. Canadian Journal of Botany 62, 2688-2729.

Silvestro D. Michalak I. 2010 - raxmlGUI: a graphical front-end for RAxML Program. and documentation available from www.sourceforge.com; Accessed August 2010.

Stamatakis A, Hoover P, Rougemont J. 2008 - A rapid bootstrap algorithmfor the RAxMLWeb Servers. Syst Biol 57, 758-771.

Tamura K, Peterson D, Peterson N, Stecher G, Nei M, Kumar S. 2011 - MEGA5: molecular evolutionary genetics analyses using maximum likelihood, evolutionary distance, and maximum parsimony methods. Molecular Biology and Evolution 28(10), 2731-2739.

Udayanga D, Liu XZ, McKenzie EHC, Chukeatirote E, Hyde KD. 2012 - Multi-locus phylogeny reveals three new species of Diaporthe from Thailand. Cryptogam Mycol 33, 295-309.

Vilgalys R, Hester M. 1990 - Rapid genetic identification and mapping of enzymatically amplified ribosomal DNA from several Cryptococcus species. Journal of Bacteriology 172, 42384246.

White TJ, Bruns T, Lee S, Taylor J. 1990 - Amplification and direct sequencing of fungal ribosomal RNA genes for phylogenetics. In: PCR Protocols, a Guide to Methods and Applications (eds. MA Innis, DH Gelfand, JJ Sninsky and J White) Academic Press. San Diego, Ca, USA 315-322.

Wijayawardene NN, Crous PW, Kirk PM, Hawksworth DL, Boonmee S, Braun U, Chomnunti P, Dai DQ, D'souza MJ, Diederich P, Dissanayake A, Doilom M, Hongsanan S, Jones EBG, Groenewald JZ, Jayawardena R, Lawrey JD, Liu JK, Lücking R, Madrid H, Manamgoda DS, Muggia L, Nelsen MP, Phookamsak R, Suetrong S, Tanaka K, Thambugala KM, Wikee S, Zhang Y, Aptroot A, Ariyawansa HA, Bahkali AH, Bhat JD, Gueidan C, De Hoog GS, Knudsen K, McKenzie EHC, Miller AN, Mortimer PE, Wanasinghe DN, Phillips AJL, Raja HA, Slippers B, Shivas RS, Taylor JE, Wang Y, Woudenberg JHC, Piątek M, Cai L, Jaklitsch WM, Hyde KD. 2014 - Naming and outline of Dothideomycetes - 2014 including proposals for the protection or suppression of generic names. Fungal Diversity 69(1), 1-55.

Wijayawardene DNN, McKenzie EHC, Hyde KD. 2012 - Towards incorporating anamorphic fungi in a natural classification-checklist and notes for 2011. Mycosphere 3(2), 157-228.

Zhang Y, Crous PW, Schoch CL, Hyde KD. 2012 - Pleosporales. Fungal Diversity 53, 1-221.

Zhang Y, Fournier J, Crous PW, Pointing SB, Hyde KD. 2009 - Phylogenetic and morphological assessment of two new species of Amniculicola and their allies (Pleosporales). Persoonia 23, $48-54$. 